\title{
Employee Share Ownership as Productivity Factor in Companies in Cameroon
}

\author{
Ousmanou Alim ${ }^{1}$ \\ ${ }^{1}$ Department of Economics and Management, University of Buea, P. O. BOX 63 Buea, Cameroon. \\ Correspondence: Ousmanou Alim, Department of Economics and Management, University of Buea, P.O.BOX 63 Buea, \\ Cameroon.
}

Received: June 14, 2016

Accepted: July 1, 2016

Available online: July 22, 2016

doi:10.11114/afa.v2i2.1759

URL: http://dx.doi.org/10.11114/afa.v2i2.1759

\begin{abstract}
This paper estimates the effects of employee ownership on productivity in companies in Cameroon. So the mechanism of employee ownership studied is the participation of employees in the capital which about 31 limited companies. These analyses are conducted of using descriptive and cross-sectional times series method on data collected during 2008-2013 from the National Institute of Statistics of Cameroon. It founds that the companies surveyed belong the whole sectors: industry $(45.2 \%)$, services $(22.6 \%)$, agriculture $(16.1 \%)$, transport $(9.7 \%)$ and trade $(6.5 \%)$. From the perspective of the workforce of employees, these companies are mostly large $(83.9 \%)$ and medium size $(16.1 \%)$. Moreover, the level of participation of employees in the capital of these enterprises is usually between $5 \%$ and $10 \%(61.3 \%)$ and the average level around $7.4 \%$. Indeed, the level average of productivity each person employed is about 11.87 million. The study concludes also the participation of employees in the capital positively and significantly affects productivity. This research, therefore devotes postulates of psychological theory on changing attitudes and behaviors of employees. The paper recommends expanding the employee ownership policy in Cameroon's companies and adequate monitoring by the government of this policy.
\end{abstract}

Keywords: Employee Ownership, Productivity per person employed, Cameroon

\section{Introduction}

The success of a company depends on the mobilization of human capital. This is stronger that the company will meet the expectations of the personal development of individuals, mobilizing human capital to increase productivity. Therefore, employee ownership is needed more today. Since the late 1980s, it has grown in most of the industrialized and emerging countries (Kuvaas, 2002). He quickly widespread to the point where in the 2000s, this phenomenon involved 25 million US employees (NCEO, 2005); 19 million European employees (Pérotin and Robinson, 2002) and 3 million employees in France (FAS, 2006).

In Africa and in Cameroon particular, although there are no accurate statistics, employee ownership is becoming more body. Indeed, the "2013 Share Plan Axa Insurance" allowed the 22,000 employees of this company to become shareholders, either in 38 countries including Cameroon. Similarly for laboratory French giant Sanofi, nearly 15000 employees in more than 80 countries (including Cameroon) subscribed approximately 1.7 million shares in 2013.

Despite the attention gives to this subject, it is difficult to find solid evidence on this theme in African literature and especially in Cameroon. The only study conducted in the Cameroonian context (to our knowledge) shows a negative relationship of employee share ownership on productivity (Ngongang, 2013). This study conducted in a context where the average level of employee participation is $2.9 \%$. Furthermore, empirical evidence on employee ownership was first sought to investigate its relationship with organizational performance. The results of these studies have proved mixed, although they generally result in either a positive effect or to negligible effects (Buchko, 1993; Gamble et al 2002. Trewhitt, 2000). However, the majority of studies extolling the benefits of employee share ownership have often supported their position by emphasizing its positive effects on the behavior and attitudes of employees (Long, 1980; Gamble et al., 2002; Caramelli, 2006; Garfatta 2010) and productivity (Collat, 1988; Ben-Ner and Jones, 1995; Jones and Jato, 1995).

Therefore, the aim of this paper is to evaluate the influence of employee ownership on productivity in companies in Cameroon with the following specific objectives: 
- To describe characteristic of companies which apply the employee ownership in Cameroon

- To determine the level of employees participation in the capital of their companies

- To examine the productivity of companies which apply the employee ownership in Cameroon

- To analyze the effect of employee ownership on productivity

- To make recommendations based on the findings of the study

The rest of the paper is organized as follows. Section 2 discusses the literature review underpinning of the study. Section 3 explains the methodology. Section 4 presents results followed by discussion on the implications of the findings of the study in section 5, while section 6 concludes the study and offers recommendations.

\section{Review of the Literature}

The assumed effects of employee ownership on productivity can be explained on, one side by the explanations of psychological theory on the attitudes and behaviors of employees (2.1) and the other by the teachings of the empirical work on the link between employee ownership and productivity (2.2).

\subsection{An explanation by the psychological theory on the attitudes and behaviors of employees}

The majority of studies on the financial contributions in general and employee share ownership in particular has been the study of its impact on employee productivity. Thus, according to some studies employee ownership positively affects productivity indirectly (Ben-Ner and Jones, 1995; Jones and Kato, 1995; Caramelli, 2006); that is how to say, the positive effects of employee ownership on productivity would not be direct but they were operating through the effects on attitudes (2.1.1) and behavior of employees (2.1.2).

\subsubsection{The effects on attitudes}

The assumed effects of employee ownership on changing employee attitudes go through motivation, job satisfaction, organizational commitment and sense of psychological ownership (Klein, 1987; Gamble et al, 2002; Caramelli,2006).

- Motivation: Several authors have suggested that employee ownership schemes increase employee motivation to work (Ben-Ner and Jones, 1995; Long, 1978a, 1978b; Klein 1987; Pierce and Rodgers, 2004) but not the proved empirically. Long (1978a and 1978b), for example, studied the respective effects of employee ownership and participation in decision-making on the various attitudes including motivation. The results showed that the relationship between employee ownership and motivation is not significant when it is positive and significant shareholders then if this is coupled with a decision (Long, 1978b). Moreover, according to the author, though there are no differences in participation levels between employee shareholders and non-shareholders, employee ownership could increase the motivation of all employees through the "pressure peers "(Long, 1978a).

- A job satisfaction: it is an attitude which is widely considered important for organizational performance. These are all feelings that employees have toward their work. According Buchko (1992), job satisfaction reflects the emotional orientation more or less positive of the job in an organization. Studies on the effects of employee share ownership have largely analyzed this attitude. A clear improvement in the job satisfaction was demonstrated by the work of Long (1978b); Greenberg (1980); Buchko (1992; 1993) and Gamble et al. (2002).

- The organizational commitment: it has had several other definitions, the most commonly accepted is that of Meyer and Allen (1997) who recognize three dimensions or aspects: emotional involvement, involvement and calculated normative implication The emotional involvement is "emotional attachment, identification and commitment in the organization" (Caramelli, 2006). Employees characterized by a strong emotional involvement remain in the organization as they wish. The extensive literature in this context, suggests that emotional involvement develops mainly by the personal realization of the employee and that translates into more efficient individuals to work (Meyer and Allen, 1997) calculated refers .Implication according Caramelli (2006), "the conscience of the costs from the organization," an employee calculated characterized by the strong of implication remains in the organization as it needs to. Empirical studies suggest that this component is developed on the basis of investment and lack of alternatives that influence the cost of a possible departure, and as a consequence that employees are more likely to stay in the organization. Finally, the normative implication is the "sense of obligation to remain in the business." In this case, an employee remains in the organization because he feels compelled to do so. This third component of the implication seems to be growing by socialization experience with the company (Caramelli, 2006) and the few studies conducted have shown positive effects of this attitude on the effort and work performance (Meyer and Allen, 1997).

- The psychological ownership or psychological sense of ownership: Pierce et al. (1991) define the psychological employee ownership as the "psychological sense of ownership more or less felt by employee shareholders." For Vandewalle et al. (1995) he has a relationship that the members of an organization have a sense of property to a "target object" speaking by standard phrases "my job" or "our organization." According to Pierce et al. (2001) the emergence of 
psychological ownership results from the basic motivation of the human being, as the need for efficiency, the need for a symbolic expression of their identity and the need to own a territory. This feeling emerges in individuals through knowledge and control of the "target object", as well as one personal investment (Caramelli, 2006). As for the psychological effects of this shareholding, Vandewalle et al. (1995) have demonstrated positive and significant relationship between psychological sense of ownership, satisfaction and organizational commitment of the employees. Another empirical study by Van Dyne and Pierce (2004), broadly confirms the results of Vandewalle et al. (1995).

\subsubsection{The effects on behavior}

Pierce et al. (1991) believe it is possible to speculate on the effects of employee ownership on a number of important behaviors for the organization. Indeed, Long (1978b) suggests that attitudes (already) mentioned employee shareholders would lead to positive behaviors. The literature knows, in this context, three key behaviors, namely: turnover, absenteeism and job performance.

Turnover: this is a behavior that is considered, according Buchko (1993) like an important in business. This is the permanent departure of employees of the organization. Empirical studies have examined the impact of employee ownership on turnover are scarce. In this context, we find the study of Wilson and Peel (1991) demonstrates that firms with profit-sharing and / or employee share ownership have significantly lower starting rates than others. Buchko (1992 and 1993), meanwhile, analyzed the effects of employee ownership on turnover through key attitudes. He calculated that, job satisfaction and organizational commitment had a history of turnover in companies with employee shareholding systems. Through a longitudinal study, Fakhfakh (2004) shows that employee ownership still has a negative and significant effect on the departure of employees. The results of all these studies show that the labor stabilization target is met when the implanting of employee ownership in the company.

Absenteeism: This is one of the productive behavior against employees in companies. Indeed, it is a costly personal issue that has aroused the attention of researchers and practitioners, which resulted in a significant body of theory (SAGIE, 1998). To our knowledge, only studies of Wilson and Peel (1991) and Brown and Fahkfakh (1999) studied the effects of profit-sharing and other forms of participation on absenteeism. The study by Wilson and Peel (1991) showed that companies adopting incentive plans and / or employee share ownership have significantly lower rates of absenteeism other. Similarly Fakhfakh and Brown (1999) found that profit-sharing and employee ownership are negatively and significantly associated with absenteeism. Indeed, under this empirical study, absenteeism is down $14 \%$ in companies with an employee share ownership plan.

Performance at work: it is a positive behavior of employees for organizations. The main studies on the effects of employee ownership on the attitudes and behavior do not have empirically analyzed the potential impact on work performance. However, and has given that employee ownership increases involvement at work (Buchko, 1992 and 1993; Pendleton et al, 1995; Kuvaas, 2003) and that involvement increases work performance, Riketta (2002) suggests that employee ownership has a positive effect on work performance of employees.

\subsection{The teachings of empirical evidence}

Empirically, Marsh and McAllister (1981) show from a sample of 229 companies, the companies with an employee stock ownership plan have an annual increasing productivity ratio of $0.75 \%$; while companies do not have to them, for decreasing productivity of $0.74 \%$. Wagner and Rosen (1985) also have confirmed this positive correlation showing that firms with a share ownership plan, beyond the conventional firms in the terms of productivity. This will peer with the conclusions of Fitzroy and Kraft (1987) which showed that employee ownership has a positive effect on productivity and financial performance.

Also in the late 1980s, several authors have highlighted the influence of employee ownership on productivity (Collat ,1988; Conte and Svejnar, 1988). The peculiarities of this work focused on the realization of these studies on listed companies (Collat, 1988) and the detection of a threshold effect because Svejnar and Conte (1988) noted that the effect of employee share ownership tends to fade with increasing percentage of employee shareholders.

In the 1990s and in the Japanese context, Jones and Kato (1993) found a significant positive correlation between employee ownership and productivity, based on a sample of 320 Japanese companies with an employee share ownership plan. The authors explain these results by the fact that most Japanese companies have mechanisms to encourage the participation of employees in profits, but also in a decision-making. Two years later, Jones and Kato (1995) show that productivity increased by $4 \%$ to $5 \%$ in companies that have implemented employee stock ownership mechanisms, and only 3-4 years after their Initial Public Offering

In the 2000s, Iqbal and Hamid (2000) conduct a study comparing the productivity of US companies with an employee share ownership plan with the companies that do not have them. The authors retain the postulates of extrinsic model of employee ownership (which takes into account the financial perspective) and the hypothesis that changes in the share price affect the motivation of the employee shareholders and therefore influence the indicators productivity. They show 
that, productivity is positively related to change in the share price for firms provided with an ESOP. Also in the American context, and it is based on the panel data for over 300 companies majority owned by employees and compared with approved enterprises, Brent (2008) shows that productivity is significantly higher for companies with an employee share ownership plan. This effect is especially important in the smaller companies.

The study Guedri and Hollandts (2008) conducted on 189 French firms observed over the period 2001-2004, shows that there is a curvilinear relationship (in inverted U shape) between employee ownership and productivity; that is to say, employee ownership is positively related to business productivity low to high levels of employee share resources and negatively to high levels with a very high employee ownership. The inflection point that the author was able to determine by $28 \%$ of the voting rights held by all employee shareholders.

Cameroon, with the exception of study Ngongang (2013) whom found a negative relationship of employee share ownership on the productivity, we know of no other evidence on this link. However, in aview of all these analyzes, this result does not preclude issuing the following statement:

Hypothesis: the participation of employees in the capital of their company has a positive impact on the productivity.

\section{Method}

The methodology is used of hypothetical-deductive; it includes the choice of the sample, the source of data, measurement of variables and the methodology of empirical tests.

\subsection{Sampling Method}

The study relied primarily on public and semi-public companies privatized in the 90s, to the extent which according to Ordinance No. 90/004 of 22 June 1990 and Decree No. 90/1257 30 August 1990 pursuant to the above order; employees held in all companies privatized 3 to $5 \%$ of the capital ${ }^{1}$. It has appeared that these companies could constitute, therefore, a satisfactory basis. The choice was made by the empirical method for convenience. This sample of 24 companies has been restricted and some categories of companies were thus withdrawn:

- Companies that have not surrendered the 5\% share capital owned by employees;

- The companies whose employees have given up employee shareholding policy;

- Banks, a credit facility and the real estate companies have given their specific financial characteristics.

Once, these restrictions have operated: three companies were removed from the sample. Subsequently, based on the ads overall ESOP in subsidiaries of large of the foreign groups, such as "Share Plan 2013" Axa Insurance SANOFI or that of 10 other companies were added to the sample ${ }^{2}$. Finally, the study is based on 31 companies with the employee shareholding policy.

\subsection{Source of data}

The data collected were a secondary source, from the INS ${ }^{3}$ database. On this basis, we found the balance sheets and accounts of the results of large companies. These documents were available after authorization from the Director General of the INS. The data (financial and accounting) are extracted from the database and is covered the period 2008-2013, 6 years.

\subsection{Measurement of variables}

It is exposed on one side, the measure of the dependent variable (productivity) and on the other hand, measures of independent variables (employee ownership and control variables).

\subsubsection{Measure of productivity}

The literature on the issue was two measures: productivity per employee and productivity of working capital (Pilverdier and Latreyte 1999). Since we were in the context of employee share is occupied productivity each person employed was chosen as a measure of productivity. It is measured as follows:

$$
\text { Productivity per person employed }=\operatorname{Ln}\left(\frac{\text { Value added }}{\text { Number of Staff }}\right)
$$

\footnotetext{
${ }^{1}$ Gicam Journal, 32, in April 2006.

${ }^{2}$ At this level we followed the news of these companies on their website during the period 2011-2015.

${ }^{3}$ The National Statistics Institute is a public administrative institution established by Presidential Decree $\mathrm{N}^{\circ} 2001 / 100$ of 20 April 2001. It is under the technical supervision of the Ministry in charge of the economy. It has legal personality and financial autonomy. Its headquarters are in Yaoundé, the political capital of Cameroon.
} 


\subsubsection{The Measure of the Employee Ownership}

Employee ownership, main explanatory variable in the productivity, is also represented by a set of indicators. Similarly to productivity, employee ownership is also quantified data. So in order to the best reflect the measures validated by previous work, Table 1 below sets out a number.

Table 1. The employee share indicators in previous work

\begin{tabular}{|c|c|}
\hline Authors & Indicators of employee ownership \\
\hline Klein (1987) & $\begin{array}{l}\text { Percentage of voting rights held by employees; } \\
\text { Percentage of capital held by employees; }\end{array}$ \\
\hline $\begin{array}{l}\text { Marsh et Mc Allister (1981), } \\
\text { Wagner et Rosen (1985); } \\
\text { Conte et Svejnar (1988); } \\
\text { Jones et Kato(1993); Iqbal } \\
\text { et Hamid (2000) Guedri et } \\
\text { Hollandts (2008a) }\end{array}$ & $\begin{array}{l}\text { Percentage of capital held by employees; } \\
\text { Binary tag (1.0) on the presence of the employee } \\
\text { shareholders capital }\end{array}$ \\
\hline
\end{tabular}

Since our sample consists only of companies with employee ownership, the measure has chosen is "the percentage of capital held by employees" as an indicator of employee ownership.

\subsubsection{Control variables}

The study includes four control variables to the best delineate and characterize the influence of the dependent variable. Their inclusion can improve the degree of external validity of the results.

As part of this research was taking them to control other variables that can influence the dependent variable in our model: productivity. The different control variables isused in this study are:

- The investment policy: investments were apprehended through tangible capital expenditures reported in net sales over the period 2008-2013. This measure was adopted by several authors including Arcimoles and Trébucq (2003).

- Margin of firms: Rappaport (1986) and Copeland et al. (1991) recommend retaining the margin of firms as predictors of productivity, gross operating margin, corresponding to the ratio between EBITDA and revenues has been incorporated into the analysis. This measure also took by Poulain-Rehm (2007).

- Activity level: the extent Rappaport (1986) and Copeland et al. (1991) were recommended to retain the level of activity as a predictor of productivity growth in revenue over the period 2008-2013 was introduced to the study. This measure was also adopted by Trébucq (2002) and Poulain-Rehm (2007).

- The size of the company: have taken into account the effect size was essential for a comparative view of the strictly financial performance of companies, and by extension, productivity. The literature shows that the "size" variable was operationalized in different ways. We have identified three measures: the number of employees, sales volume and total assets. As part of our study and how to Tréboucq (2002), Poulain-Rehm (2007) and Gharbi and Lepers (2008), we hold as a measure of the "size of the company," the neperien logarithm of total assets.

Table 2. Summary of variables and measure adopted

\begin{tabular}{lll}
\hline & Indicators & Designation \\
\hline Productivity & $\begin{array}{l}\text { Dependant variables } \\
\text { Productivity each person employed } \\
\text { Independant variables }\end{array}$ & PPE \\
Employee ownership & $\begin{array}{l}\text { Percentage of capital held by employees } \\
\text { Control variables }\end{array}$ & PKEM \\
Investment policy & Fixed Assets/Net Sales & INV \\
Margin of firms & EBITDA / net sales & MOF \\
Activity Level & Revenue growth excluding tax & GROW \\
Size & Logarithm of total assets & SIZE \\
\hline
\end{tabular}

\subsubsection{Methodology empirical tests}

Analysis of productivity will be achieved through a multiple regression panel (cross-sectional times series). Therefore, this research model is as follows: 


\section{Dependent Variable $_{i t}=c+$ independent Variables ${ }_{i t}+\beta$ Control Variables ${ }_{i t}+\varepsilon_{i t}$}

With c: a constant; $\boldsymbol{\alpha}$ and $\boldsymbol{\beta}$ : the variable estimators; and $\boldsymbol{\varepsilon}$ : an error term $\mathrm{i}=\{1 ; \ldots ; 31\}$ and $\mathrm{T}=\{1, \ldots, 6\}$.

Specifically, the following model is necessary for setting the empirical test of the theoretical hypothesis already formulated.

$$
P P E_{i t}=c+\alpha P K E M_{i t}+\beta_{1} I N V_{i t}+\beta_{2} M O F_{i t}+\beta_{3} G R O W_{i t}+\beta_{4} S I Z E_{i t}+\varepsilon_{i t}
$$

To perform empirical analysis panel data, various tests have been established: the test of the presence of individual effects to the extent in panel depleted, it is necessary to check if there is a presence individual effect in the data. The Hausman test to specify whether the model is fixed or random effects and Breusch- Pagan test to measure the significance of random effects.

\section{Results}

We examine in this part, the characteristics of the sample of companies and the impact of employee ownership on the productivity.

\subsection{The Profile of the Companies of Sample}

The profile of the companies covered the presentation of descriptive statistics of sample characteristics, the level of participation of employees in the capital and the productivity.

The sample of the study includes 31 companies with employee ownership with the majority for over 10 years (83.9\%). They are all limited companies (SA) and mainly belong to the industrial sector (45.2\%) and the services sector (22.6\%), agriculture (16.1\%), transport $(9.7 \%)$ and trade $(6.5 \%)$. The majority of these companies have 10 years and over of age $(93.5 \%)$; only $6.5 \%$ of these have between 5 and 10 years.

According to the criterion of the workforce of employees, these companies are mostly large, employing over 100 employees (83.9\% of the sample), only $16.1 \%$ employ between 20 and 100 employees (Averages companies). Finally, $77.4 \%$ of these companies are firms whose capital is controlled by the foreign entrepreneurs and $22.6 \%$ are firms controlled by the Cameroonian entrepreneurs. Table 3 below gives the characteristics of companies with employee ownership.

Table 3. Characteristics of Companies with Employee Ownership

\begin{tabular}{lccccc}
\hline Activity Area & Frequency $(\%)$ & Age of the company & Frequency $(\%)$ & Number of employees & Frequency $(\%)$ \\
\hline Industry & 45.2 & 5 to 10 years & 6.5 & 20 to 100 employees & 16.1 \\
Service & 22.6 & 10 and over & 93.5 & 100 and more employees & 83.9 \\
Agriculture & 16.1 & & & & \\
Transport & 9.7 & & & & \\
Trade & 6.5 & & 100 & & 100 \\
TOTAL & 100 & & & & \\
\hline
\end{tabular}

In terms of the level of participation of employees in the capital, the results show that in the majority of firms in the sample, the level of participation of employees in the capital are between 5 and 10\% (61.3\%). However, in $22.6 \%$ of these companies this level is below $5 \%$ and in $16.1 \%$ it is above $10 \%$. Similarly the average level of participation is about 7.4\% of capital. This result is high unlike the Ngongang (2013) whom found an average level of $2.9 \%$. Thus, this result can be explained by the fact that most of the privatized companies were reversed from 5\% of employees under Ordinance No 90/004 of 22 June 1990 and also by the establishment of Global employee share plans as the "Share Plan 2013 AXA Insurance and SANOFI." Table 4 below shows the level of participation of employees in the capital.

Table 4. Level of participation of employees in the capital of their company

\begin{tabular}{lr}
\hline Designations & Frequency $(\%)$ \\
\hline Less than $5 \%$ & 22.6 \\
Between $5 \%$ and $10 \%$ & 61.3 \\
$10 \%$ and over & 16.1 \\
TOTAL & 100 \\
\hline
\end{tabular}

Regarding productivity, Table 5 below gives the descriptive statistics of productivity in these companies 
Table 5. Descriptive statistics of productivity

\begin{tabular}{ccccc}
\hline Elements & Minimum & Maximum & Mean & Standart deviation \\
\hline PPE & 14.08 & 17.96 & 16.29 & 1.003 \\
\hline
\end{tabular}

From the results of Table 5, we observe that the minimum of productivity each person employed in these companies is at 14.08 approximately $1,302,765$ CFA francs and the maximum 17.96 which approximately corresponds to $63,085,404$ FCFA. The average of 6 years is 16.29 which corresponds to 11, 875, 642 FCFA.

\subsection{Analysis of the impact of employee ownership on productivity}

Recall here that the results of the bivariate analysis shows that all Pearson correlation coefficients are below 0.7, limit from which we usually start to have a serious problem of multi collinearity (Kervin, 1992 ). This then indicates the absence of multi collinearity between independent variables included in the multiple linear regression model.

Table 6.Correlation matrix of the independent variables

Pkem inv mof acti size
pkem |1.0000
inv $\mid-0.36651 .0000$
mof $\mid-0.2560 \quad 0.44621 .0000$
acti $\mid-0.1656 \quad-0.0410 \quad-0.38671 .0000$
size $\mid 0.0329 \quad-0.0398 \quad 0.0296 \quad-0.09481 .0000$

4.2.1 Results of statistical tests and choice of estimation method for model

Regarding the results of specification tests of the effects, Table 7 below summarizes this model, the number of observations (N), the statistical value F after estimates Ordinary Least Squares (OLS), presence individual effects, the value of the chi-square statistic from the Hausman test, the nature of the effect and the method of estimation.

Table 7. Results of statistical tests and choice of estimation method for model

\begin{tabular}{cccccccccc}
\hline Model & Sample & $\begin{array}{c}\text { Number of } \\
\text { observations }\end{array}$ & Statistic-F & P-value & $\begin{array}{c}\text { Presence of } \\
\text { individual } \\
\text { effect }\end{array}$ & $\begin{array}{c}\text { Chi-square } \\
\text { of Hausman }\end{array}$ & $\begin{array}{c}\text { P-value } \\
\text { Nature of } \\
\text { individual } \\
\text { effect }\end{array}$ & $\begin{array}{c}\text { Method of } \\
\text { estimation }\end{array}$ \\
\hline $\mathrm{M}$ & 31 & 186 & 182.5 & $(0.000)^{* * *}$ & Yes & 32,32 & $(0.000)^{* * *}$ & Fixed & Within \\
\hline
\end{tabular}

Thresholds of Significance: $* * * \mathrm{p}<0.01, * * \mathrm{p}<0.05, * \mathrm{p}<0.1$

The model is then fixed effects. Therefore, the quality of the model will be examined by the correlation coefficient $\mathrm{R} 2$ (Within) and the F statistic

4.2.2 A statistically significant effect of employee share ownership on productivity

As part of our empirical study, the link between employee ownership and productivity is examined through the test of the hypothesis, formulated as: "the participation of employees in the capital of their company has a positive impact on the productivity». Table 8 below summarizes the results of the estimation of this model.

Table 8 . Results of regressions estimating the effect of employee participation in their company capital on productivity

\begin{tabular}{lccc}
\hline & & Model & \\
Variables & Coefficient & t-statistic & $(0.001)^{* * *}$ \\
\hline PKEM & 30.40 & 3.64 & $(0.30)^{* * *}$ \\
INV & 0.09 & 1.03 & $(0.002)^{* * *}$ \\
MOF & 1.83 & 3.16 & $(0.015)^{* * *}$ \\
ACTI & 0.54 & 2.46 & $(0.881)^{* *}$ \\
SIZE & -0.021 & -0.15 & $(0.002)^{* * *}$ \\
Constant & 14.15 & 3.14 & \\
\hline
\end{tabular}

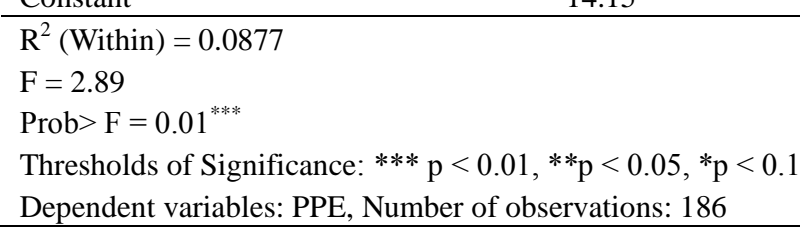

In terms of the impact on the productivity, analysis of the results reveals that the model used is explanatory productivity. The $\mathrm{R} 2$ coefficient (Within) is in the range of 0.0877 and quality of fit of the model is satisfactory $(\mathrm{F}=2.89$, significant 
at the $1 \%$ level).

In addition, the results presented in the table above show that the participation of employees in the capital has a positive and statistically significant impact (at 1\% level) on productivity. The hypothesis that assumes a positive relationship between employee participation in the capital in their company and productivity is then confirmed. At the same time, the model highlights the impact of the growth in activity and margins of firms, as required by the theory. The influence of an increase in turnover is statistically significant at the $1 \%$. The influence of the margin of firms appears even higher at the $1 \%$. However, the investment policy of the variables and size has no statistically significant effect.

\section{Discussion}

We interested in the empirical verification of the hypothesis formulated, the results off a pronounced positive effect of employee share ownership on productivity. This can be interpreted by the fact that equity favors changing attitudes and behaviors of employees.

Indeed, this incentive scheme encourages employees increasing work motivation (Ben-Ner and Jones, 1995; Pierce and Rodgers, 2004). Similarly employee ownership increases job satisfaction. This was reported by Gamble et al. (2002) stressing that employee ownership increases feelings that employees have toward their work. Pendleton et al. (1998) adds in this context that "employee share ownership can lead to a sense of psychological ownership, which in turn can lead to involvement and greater employee satisfaction."

Moreover, we can also explain this result through changes in employee behavior. At this level, Wilson and Peel (1991) show that companies with employee shareholders present the starting rate significantly lower than the others. Similarly, companies adopting ESOP have significantly lower rates of absenteeism to others (Wilson and Peel, 1991). So, employee ownership increases involvement at work (Buchko, 1992; 1993) and that involvement increases work performance (Riketta, 2002).

Empirically, this result strengthens the conclusions of Marsh and McAllister (1981); Conte and Svejnar (1988), and Guedri and Hollandts (2008a) have shown that employee ownership has a positive effect on productivity. However, in the same context of Cameroon, Ngongang (2013) finds no effect of employee share ownership on productivity. This contradictory result may be explained by the level of employee participation in the capital of their business which was around $2.9 \%$ in Ngongang (2013), which is relatively low. Consequently, the low turnout may not a factor of motivation of employee shareholders and this explains the lack of effect on productivity. Meanwhile, in the case of this study, the average rate of the participation of employees in the capital is about $7.4 \%$. This very high rate compared to that of Ngongang (2013) may explain this result.

\section{Conclusion}

The main objective of this study was to evaluate the influence of employee ownership on productivity. Specifically, we have assumed, building on previous work that employee ownership has an impact on productivity. To verify these assumptions, a multiple regression panel was applied to the variables of employee ownership and productivity.

Overall, the participation of employees in the capital of their company has a positive and significant impact on productivity. In addition to employee ownership, gross operating margin (MOF) and the level of activity (ACTI) has a positive and significant impact on the threshold of $1 \%$ on productivity.

A thorough analysis of the effects of employee ownership on productivity such as the percentage of capital held by employees reveals that the phenomenon has a considerable positive impact on the productivity each person employed. As a result in order to improve the employee share ownership policy in the long run, the following subtle points need to be enforced. One, companies applying the employee share ownership policy such open up further and significantly the capital of their employment. Two, the government must create a legal framework that can regulate and encourage companies to open the capital of their employees so that employee ownership is a global phenomenon in Cameroonian companies not a tool reserved for a business categories. For now, outside of Ordinance No. 22/004 of 22 June 1990, which specifies the possibility of opening the capital to employees in privatized companies, no legal framework, to our knowledge, doesn't exists in this direction.

It is important to stress at the end of this study, the results should be taken with great caution. This one hand, because of the representativeness of the sample related to the sampling method (empirical for convenience) and the sample size (reduced); secondly, this study was done in a context of lack of efficient financial market. Mainly, the empirical convenience sampling method does not allow us to generalize the results.

\section{References}

Arcimoles (d'), C. H., \& Tréboucq, S. (2003). Une approche du rôle de l'actionnariat salarié dans la performance et le risque des entreprises françaises. Revue de Gestion de Ressources Humaines, 48, 2-15. 
Ben-Ner, A., \& Jones, D.C. (1995). Employee participation, ownership, and productivity, a theoretical frame framework, Industrial Relations, 34(4), 532-554.

Blair, M. M., \& Kochnan, T. A. (2000). The New Relationship: Human Capital in the American Corporation. D.C: Brooking Institution Press.

Brent, K. (2008). Employee ownership and participation effects on firm outcornes. City University of New York.

Brown, S., \& Fakhfakh, F. (1999). Absenteeism and employee sharing: an empirical analysis based on french panel data. 1981-1991. Industrial and Labor Relations Review, 52(2), 234-251.

Buchko, A. A. (1992). Effects of employee ownership on employee attitudes- a test of three theoretical perspectives. Work and Occupations, 19(1), 59-78

Bucho A. (1993).The effects of employee ownership on employee attitudes: an integrated causal model and path analysis. Journal of Management Studies, 30(4), 633-657.

Caramelli, M. (2006). Une étude de l'actionnariat des salariés dans le contexte de l'entreprise multinationale: une approche attitudinale interculturelle. Thèse de Doctorat en Sciences de Gestion, Université de Montpellier II.

Collat, D. (1988). In employee ownership and corporate performance: a comprehensive review of evidence. National Center for Employee Ownership. http: //www.nceo.org

Conte, M. A., \& Svejnar, J. (1988). Productivity effects of worker participation in management, profit sharing, worker ownership of asset and unionization in U.S firms. International Journal of Industrial Organization, 139-161.

Copeland, T., Koller, T., \& Murrin, J. (1991). La stratégie de la valeur. Interdictions.

Dondi, J. (1992). Contribution à la connaissance de l'actionnariat des salaries. Thèse de Doctorat en Sciences de Gestion, Université Bordeaux I.

Employees' Perception of Fairness and their Preference for company Share over Cash. Scandinavian Journal of Management, Article in Press, Uncorrected Proof, Available online 6 January 2002.

Fakhfakh, F. (2004). The effect of profit sharing and employee share ownership on quits: evidence from a French panel firms, employee participation, firm performance and survival. Advances in the Economic Analysis of Participatory and Labor Managed Firms, 8, 129-147.

FAS (2006). Guide de l'actionnariat salarié. ${ }^{\text {ème }}$ Edition.

Fitzroy, F., \& Kraft, K. (1987).Cooperation, productivity and profit sharing. Quartely Journal of Economics, 102(1), 23-35.

Gamble, J. E., Culpepper, R., \& Blubauch, M. (2002). ESOPs and employee attitudes: the importance of empowerment and final value. Personnel Review, 31(1), 9-26.

Garfatta, R. (2010). Actionnariat salarié et création de valeur dans le cadre d'une gouvernance actionnariale et partenariale: Application au contexte français. Thèse de Doctorat, IAE, Université de Bourgogne, http://tel.archivesouvertes. fr/docs/00/59/28/PDF/these_A_GARFATTA_-_Riath_2010.pdf

Greenberg, E. S. (1980). Participation in industrial decision-making and worker satisfaction: the case of producer cooperatives. Social Science Quarterly, 60(4), 551-569.

Guedri, Z., \& Hollandts, X. (2008a).Beyond dichotomy: The culvilinear impact of employee ownership on firm performance. Corporate Governance: An international Review, 16(5), 460-464.

Iqbal, Z., \& Hamid, S. (2000). Stock price and operating performance of ESOP firms: a time-series analysis. Quartely Journal of Business and Economics, 33(9), 25-47.

Jones, J. C., \& Kato, T. (1993). The scope, nature and effects of employee stock ownership plans in Japan. Industrial and Labor Relations Review, 46(2), 352-367.

Jones, J. C., \& Kato, T. (1995). The productivity effects of employee ownership plans and bonuses: evidence from Japanese panel data. American Economic Review, 85, 391-415.

Kervin, J. B. (1992). Methods for business research. New-York: Haper Collins.

Klein, K. (1987). Employee stock ownership and employee attitudes: A test of three models. Journal of Applied Psychology, 73(4), 319-332.

Kuvaas, B. (2002). Employee Ownership and Effective Organizational Commitment:

Leana, C., \& Van, B. H. (1999).Organizational social capital and employment practices.Academy of Management Review, 24(3), 538-555. 
Long, R. J. (1978a). The Effects of Employee Ownership on Organizational Identification, Jop Attitudes and Organizational Performance: a Tentative Framework and Empirical Findings. Human Relations, 31(1), 29-48.

Long, R. J. (1978b).The relative effects of share ownership versus control on job attitudes in an employee-owned company.Human Relations, 31(9), 753-763.

Long, R. J. (1980). Job attitudes and organization performance under employee ownership.The Academy of Management Journal, 23(4), 726-737.

Marsh, T., \& McAllister, D. (1981). ESOPs tables: a survey of companies with employee stock ownership plans. Journal of Corporation Law, 6(3), 551-623.

Meyer, J. P., \& Allen, N. J. (1991). A three-component conceptualization of organizational commitment: same methodological consideration. Human Ressource Management Review, 1, 61-98.

NCEO (2005). Données disponibles sur http://www.nceo.org/library/eo_stat.html,10/03/2016

Pendleton, A., McDonald, J., Robinson, A., \& Wilson, N. (1995). The Impact of Employee Share ownership Plans on Employee Participation and Industrial Democracy. Human Ressource Management Journal, 5(4), 44-60.

Pendleton, A., Wilson, N., \& Wright, M. (1998).The Perception and of Industrial Relations, 36(1), 99-123.

Perotin, V., \& Robinson, A. M. (2003). Participation aux bénéfices et actionnariat salarié: les éléments du débat. Luxembourg: Document de Travail pour le Parlement Européen, Direction Générale des Etudes, Série «Affaires Sociales », SOCI 109 FR.

Pierce, J. L., \& Rodgers, L. (2004). The Psychologie of ownership and worker-owner productivity.Group and Organization Management, 29(5), 588-613.

Pierce, J. L., Kostova, T., \& Dirks, K.T. (2001). Toward a theory of psychological ownership in organization.Academy of Management Review, 26(1), 298-310.

Pierce, J. L., Rubenfeld, S. A., \& Morgan, S. (1991). Employee ownership: a conceptual model of process and effects. Academy of Management Review, 16(1), 121-144.

Pilverdier-Latreyte, J. (1999). Finance d'entreprise, Economica. $7^{\text {ème }}$ Edition, Paris.

Poulain-Rehm, T. (2007). L'actionnariat salarié en France, un facteur de création de valeur?. Banque\& Marché, 88, 25-35.

Rappaport, A. (1986). Creating shareholder value: the new standards of business performance. Free Press.

Riketta, M. (2002). Attitudinal Organizational Commitment and Job Performance: a Meta-Analysis. Journal of Organizational Behavior, 23(3), 257-266.

Sagie, A. (1998). Employee absenteeism, organizational commitment and job satisfaction: another look. Journal of Vocational Behavior, 52(2), 156-171.

Thiétardt, R. A. (1999).Validité et fiabilité de la recherche », in Méthode de Recherches en Management. Thietard R-A (ed), 257-287.

Tréboucq, S. (2002). L'actionnariat salarié dans les entreprises familiales du SBF 250: un outil de création de valeur ?, Revue Finance Contrôle Stratégie, 15(4), 107-453.

Trewhitt, L. (2000). Employee buyouts and employee involvement: a case study investigation of employee attitudes. Industrial Relations Journal, 31(5), 437-453.

Vandewalle, D., Van, D. L., \& Kestova, T. (1995). Psychological ownership: an empirical examination of its consequences. Group and Organization Management, 20(2), 210-226.

Wagner, I., \& Rosen, C. (1985). Participation's effect on performance and satisfaction: a reconsideration of research evidence. Academic of Management Review, 19(2), 312-330.

Wilson, L., \& Peel, M. (1991). The impact on absenteeism and quits of profit sharing and other forms of employee participation. Industrial and Labor Relations Review, 44(3), 454-468.

\section{(c) EY}

This work is licensed under a Creative Commons Attribution 3.0 License. 